\title{
Screening for Bioactive Extracts and Targeted Isolation of Antimicrobial Agents from the Stem Bark of Adenanthera pavonina $L$.
}

\author{
K. Abdu ${ }^{1}$ and M. Adamu' ${ }^{2 * *}$ \\ ${ }^{1}$ Department of Pure and Industrial Chemistry, Bayero University, Kano, P.M.B. 3011, BUK, Kano, \\ Nigeria \\ ${ }^{2}$ Department of Chemistry, Nigerian Army University Biu, No. 1 Biu, Gombe Road, P.M.B 1500 Biu, \\ Borno State, Nigeria \\ *Corresponding author's e-mail: adamumamman360@gmail.com
}

\begin{abstract}
Bioactive secondary metabolites can be isolated from medicinal plants as antimicrobial agents. Based on ethnopharmacological relevance, Adenanthera pavonina $L$. is recognized as a plant with good medicinal values and forms the integral part systems of traditional medicine in Borno state, and other parts of Nigeria. Despite the widespread used, most of the information available to consumers about the plant is not backed by credible scientific data. Only a limited number of studies have probed into the scientific evidence for bioactivity and safety of this medicinal plant. Such studies rarely progress to isolation and evaluation of the active antimicrobial agents. In the present study, four solvent-extract (ethanol, ethyl acetate, chloroform and n-hexane) were subjected to antimicrobial activity test against $E$. coli (E.C), S. typhi (S.T), S. aureus (S.A), A. flavus (A.F), C. albican (C.A) and M. specie (M.S) and toxicity test against Artemia salina. The ethyl acetate extract showed outstanding activity against the microbes (bacteria and fungi) and Artemia salina, respectively. The activity and toxicity effects of the ethyl acetate extract suggests the presence of active antimicrobial agents and hence provides a way forward for column chromatographic isolation of the targeted Antimicrobial agents. The targeted compounds isolated (AP- $\mathrm{X}_{38}$ and $\mathrm{AP}-\mathrm{X}_{44}$ ) were also subjected to antimicrobial test using three bacterial species and found to be even more active that the solvent extract of ethyl acetate. This study justifies part of ethno medicinal claims on the plant.
\end{abstract}

Received: August 4, 2020; Accepted: September 2, 2020

Keywords and phrases: Adenanthera pavonina, cytotoxicity, Artemia salina, extracts, antimicrobial agents.

Copyright (C) 2020 K. Abdu and M. Adamu. This is an open access article distributed under the Creative Commons Attribution License, which permits unrestricted use, distribution, and reproduction in any medium, provided the original work is properly cited. 


\section{Introduction}

Adenanthera pavonina is well-known for its medicinal value in folk medicine in Borno state and other parts of Nigeria. It is widely used in the treatment of mastitis and other ailments like: Pile, diarrhoae, ulcer, healing of open wound, skin diseases among others (Abdu and Adamu [1]). The plant is also grown in Asian countries (Malaysia, India, Bangladesh and China) as an ornamental crop and commonly known by English names as coral wood, red sandal wood, red lucky tree, red bead tree, food tree among others (Ezeagu et al. [2]). It is a deciduous tree, about 6-15 $\mathrm{m}$ tall, erect and up to $45 \mathrm{~cm}$ in diameter depending on the location (Orwa et al. [3] and Chopra et al. [4]).

The stem-bark of the plant is traditionally used for treatment of various disease conditions like gonorrhea, haematuria, ulcers, it is astringent, vulnerary and aphrodisiac in nature (Hussain et al. [5]). The plant is endowed with tremendous potentials in both healthcare and trade, but limited numbers of studies have probed into the scientific evidence for bioactivity and safety of this medicinal plant in Borno state and other parts of Nigeria. Mathew et al. [6] reported that, considerable work has been done to explore the biological activity and medicinal applications of the plant (Adenanthera pavonina), still there are available countless possibilities of pharmacological applications which needs to be explored, because Abdu and Adamu [7] reported that, phytochemical screening of stem bark of Adenanthera pavonina uncovered the presence of alkaloids, phenols, flavonoids, sterols, tannins, glycosides among others in different extracts. These constituted number of phytochemicals imbedded in A. pavonina disclosed its uses for various therapeutic purposes as in the treatment of various health illness and act as hepatoprotective, anti-hyperlipidemic, anti-nociceptive, anti-diarrhoeal, antioxidant, anticancer, antimicrobial, inhibitor of nephrolithiasis and carcinogenesis (Mujahid et al. [8]).

Different parts of Adenanthera pavonina (roots, stem-bark, leaves and seeds) have been used for the treatment of different human disorders like chronic rheumatism, diarrhea, dysentery antiseptic paste, pulmonary affections, chronic ophthalmia, and reported to have properties such as antioxidant, antibacterial by Jayasinghe et al. [9]. The plant has been reported to demonstrate anti-inflammatory and analgesic activities (Olajide et al. [10] and Jayakumari et al. [11]), antihypertensive effect (Adedapo et al. [12]), antifungal (Soares et al. [13]), anti-oxidant (Mujahid et al. [14]), anticancer (Chauhan et al. [15], Kumar et al. [16]), hepatoprotective (Mujahid et al. [17]), renal protective (Pandhare et al. [18]), anti-hyperlipidemic (Das et al. [19]) and antibacterial (Hussain et al. [20], Adeyemi et al. [21]). The medicinal properties of the plant are due to 
the presence of flavonoids (Rastogi and Mehrotra [22]), glycosides (Yadav et al. [23]), saponins and steroids (Khare [24], Orwa et al. [3]).

Adenanthera pavonina $L$. belongs to Fabaceae family. The scientific name is derived from a combination of two Greek words aden, "a gland," and anthera, "anther" (Khan and Khanum [25]). It is commonly known by English names as coral wood, red sandal wood, red lucky tree, red bead tree, red bread tree, food tree and also known by vernacular names Raktakambal, Manjadi, Anikundumani, Lopa (Hindi), Raktakambal (Bengali), among other (Chopra et al. [4], Binggeli et al. [26], Orwa et al. [3], Mathew et al. [6]).

Adenanthera pavonina $L$. is a plant naturally grown in the southern part of Borno, Nigeria and is well known to Babur/Bura people of the state by a local name "Ghrini". It is a medium-sized to large deciduous tree about 8-14 m tall and 40-45 cm thick, depending on location. Generally, the plant is erect with a dark brown to greyish bark and a soft-pale brown inner bark. It bears leaves, flowers and seeds. The leaves are bi-pinnate in nature with 8-21 leaflets on short stalks, which turns yellow with age (Abdu and Adamu [1]).

\section{Materials and Methods}

\section{Sample Collection and Authentication}

Fresh stem bark sample along with leaves and seeds of the plant were collected from Kwaya Bura village, Hawul Local Government, Borno State, Nigeria. The plant was identified at the Department of Plant Biology, Bayero University, Kano, Nigeria. A text report from Herbarium unit of the department confirmed the authenticity of the plant material as Adenanthera pavonina L. with accession number 0493.

Figure 1 shows pictures of leaves and seeds of Adenanthera pavonina that helps in the identification and authentication of the plant.

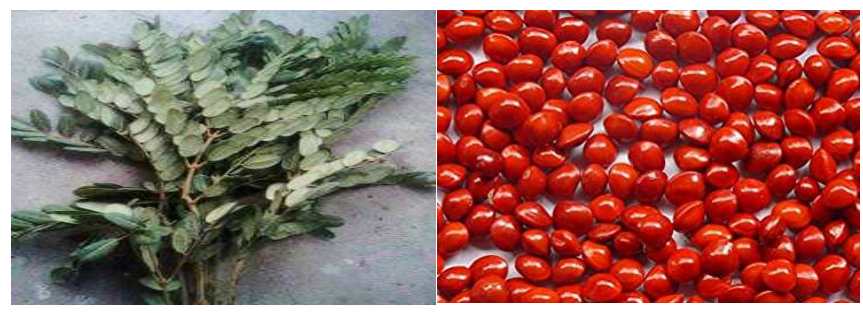

Figure 1. Picture of leaves and seeds of A. pavonina. 


\section{Sample Preparation}

Fresh stem-bark of Adenanthera pavonina $L$. was washed with distilled water, cut into smaller pieces and air dried under shade at ambient temperature for about three (3) weeks. It was then pulverized mechanically to form a coarse powder. The powdered sample was stored in an air tight container in cool and dry place away from any form of contaminant and was later subjected to extraction using different solvents (ethanol, ethyl acetate, chloroform and n-hexane).

Figure 2 is a representation of A. pavonina stem bark sample (A: unwashed-fresh stem bark, B: washed-fresh stem bark, C: sliced-fresh stem bark and D: powdered-stem bark).

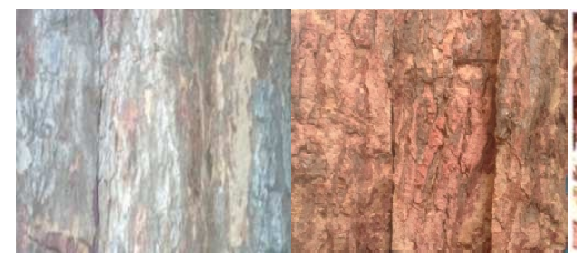

A

B

C

D

Figure 2. Pictures showing fresh and dried grounded stem bark of A. pavonina.

\section{Solvents Extraction}

Each of the powdered sample (200 g) were introduced into Four (4) different amber bottles labeled (W, X, Y and Z) and percolated with 1.0 L of ethanol (W), ethyl acetate $(\mathrm{X})$, chloroform $(\mathrm{Y})$ and $\mathrm{n}$-hexane $(\mathrm{Z})$ with shaking at regular intervals for one week. Their extracts were separated from the debris by filtration. The filtrates were concentrated using a rotary vapour $\left(\mathrm{R} 110\right.$ at $\left.40^{\circ} \mathrm{C}\right)$ and then coded as AP-W, AP-X, AP$\mathrm{Y}$ and AP-Z. They were weighed, kept in a cool and dry place away from any form of contaminant (Sarkar et al. [27]).

\section{In vitro Antimicrobial Activity}

\section{Test Organisms}

Standard clinical bacterial and fungal isolates obtained from Microbiology Department, Bayero University, Kano, were used in this assay. These bacterial isolates were gram negative and positive including E.coli, S.typhi and S.aureus respectively and fungal isolates including: A.Flavus, C.albican and M. specie. 


\section{Preparation of Stock Solutions and Working Concentrations}

The stock solutions of the extracts were prepared by dissolving each extract (60.0 $\mathrm{mg}$ ) in $1.0 \mathrm{~mL}$ DMSO separately to produce $60.0 \mathrm{mg} / \mathrm{mL}$. From each stock solution, solutions of lower concentrations $(30.0$ and $15.0 \mathrm{mg} / \mathrm{mL})$ were obtained using serial double dilution (SDD).

\section{Antimicrobial Screening (Agar Well Diffusion Method)}

Antimicrobial (antibacterial and antifungal) activity of the extracts and isolated compounds were screened using agar well diffusion method. In this method, nutrient agar (NA) and potatoes dextrose agar (PDA) plates were swabbed with eight-hours-old broth culture of bacteria and fungi using sterile cotton swab respectively. On each sensitivity disc, four wells (6 mm each) were made using a sterile Cork borer and three different concentrations $(60.0,30.0$ and $15.0 \mathrm{mg} / \mathrm{mL})$ of ethanol extract (AP-W), ethyl acetate extract (AP-X), chloroform extract (AP-Y) and n-hexane extract (AP-Z) were impregnated $(100 \mu \mathrm{L})$ in to each well using a sterile micropipette to investigate the dose dependent activity of the extracts on both standard bacterial and fungal isolates in use. At the same time Gentamicin, $125 \mathrm{mg} / \mathrm{mL}$ and Ketoconazole, $100 \mathrm{mg} / \mathrm{mL}$ were used as standard. The sensitivity plates were incubated at $37^{\circ} \mathrm{C}$ for about 24 hours. The diameter of zones of inhibition around each well was noted and the values were measured for the eventual antimicrobial activity (Azoro [28], Renilda et al. [29], Balouiri et al. [30]).

\section{Lethality Assay using Artemia Cyst (Brine Shrimp)}

\section{Hatching of Artemia Cyst}

Artemia Cyst (Brine shrimps) collected from Professor O.A Adoum, Department of Pure and Industrial Chemistry, Bayero University, Kano, was used as the test organism. Natural sea water $(100 \mathrm{~mL})$ was taken in a beaker $(500 \mathrm{~mL})$ and Artemia Cyst $(6.4 \mathrm{~g})$ was added. The Cyst started hatching after $48 \mathrm{hrs}$ and was allowed to stand for about $72 \mathrm{hrs}$ for complete hatching and the shrimps were matured as nauplii in the presence of light. This process is carried out under cross ventilation in order to ensure constant supply of oxygen and the nauplii were taken for this assay (Saha et al. [31]).

\section{Preparation of Stock Solutions and Working Concentrations}

The ethanol extract $(20 \mathrm{mg})$ and ethyl acetate extract $(20 \mathrm{mg})$ were separately dissolved in methanol ( $2 \mathrm{~mL})$ to obtain $20,000 \mu \mathrm{g}$ per $2 \mathrm{~mL}$ stock solutions. From each stock solution of the extract, series of solutions of lower concentrations $(1000,100$, and 
$10 \mu \mathrm{g} / \mathrm{mL}$ ) were obtained by two-fold serial dilution and were used for the assay (McLaughlin et al. [32], Otang et al. [33]).

Potassium dichromate as a cytotoxic agent was used as a positive control. It was prepared by dissolving $20 \mathrm{mg}$ in Seawater $(2 \mathrm{~mL})$ and then serially diluted to solutions of different concentrations $(1000,100$ and $10 \mu \mathrm{g} / \mathrm{mL})$. Seawater was used as a negative control (Unuofin et al. [34]).

The standard solutions of the ethanol extract (AP-W), ethyl acetate extract (AP-X) and potassium dichromate (positive control) were impregnated into dry and clean glass tubes in three (3) replicates of each concentration and the glass-tubes were allowed to stand for 24 hours away from any form of contaminant for the diluting solvent to evaporate. After evaporation, few drops of DMSO were introduced in to each test-tubes and Sea water $(2.5 \mathrm{~mL})$ was filled into each to make it ready for the application of brine shrimps nauplii (Otang et al. [33], Asaduzzaman et al. [35]).

\section{Lethality Assay Procedure}

With the help of Pasteur pipette, ten (10) living and healthy brine shrimp nauplii along with Seawater were introduced into each test-tube containing the test solution of the sample and the control solutions up to the pre-marked volume $(5 \mathrm{~mL})$ on the glass tube. For convenient application, a magnifying glass was used for counting the nauplii and also to avoid taking Artemia Cyst in to the test-tube (Saha et al. [31]). After 24 hours incubation, the same magnifying glass was used for convenient counting of the survived shrimp nauplii in each test-tube and the results obtained were recorded. From these results, the percentage mortality of shrimp nauplii was calculated for each concentration using the equation three (3) below (Unuofin et al. [34]).

$$
\% \text { Mortality }=\frac{\text { Total nauplii }- \text { Living nauplii }}{\text { Total nauplii }} \times \frac{100}{1} \rightarrow
$$

\section{Column and Thin Layer Chromatography}

The Ethyl acetate extract (AP-X) of stem bark of Adenanthera pavonina L. was subjected to silica gel chromatographic isolation. About $5.0 \mathrm{~g}$ of this extract (AP-X) was mixed with silica gel $(10 \mathrm{~g})$ and $10 \mathrm{~mL}$ of solvent (ethyl acetate) in a glass beaker (50 $\mathrm{mL}$ ). The mixture was stirred thoroughly to facilitate mixing and drying. The sample was then loaded and then $10 \mathrm{~g}$ silica gel was added as a protective layer to the sample in the glass colunm. The content within the chromatographic column was eluted with ratios of different solvent mixtures (n-hexane-ethylacetate, followed by ethylacetate-methanol) 
based on polarity gradient. Fractions $\left(\mathrm{APX}_{1}-\mathrm{APX}_{61}\right)$ were collected in labeled bottles based on colour and quantity at different time intervals and were monitored using thin layer chromatographic analysis. Fraction that appeared as a single spot on TLC plates were selected and their $\mathrm{R}_{\mathrm{f}}$ values were calculated using the following expression.

$$
\mathrm{R}_{\mathrm{f}}=\frac{\text { Distance travelled by spot }}{\text { Distance travelled by solvent front }} \rightarrow
$$

\section{Results and Discussion}

\section{Extraction}

Table 1 presents the physical properties of four different solvent-extracts of stem bark of Adenanthera pavonina. It is seen from this table that, ethanol extract (AP-W) and ethyl acetate extract (AP-X) gave good yield, chloroform extract (AP-Y) gave small yield and n-hexane extract (AP-Z) presented the least yield. This finding entails that, the stem bark of A. pavonina contained much polar compounds than non-polar. This is because, the four different solvent-extracts presented were obtained from same mass $(200 \mathrm{~g})$ of plant sample using same volume $(1.0 \mathrm{~L})$ of different solvent of varying polarity gradient.

Table 1. Physical properties of the four extracts.

\begin{tabular}{ccccc}
\hline Extract & Colour & Texture & Weight $(\mathbf{g})$ & \% Yield \\
\hline AP-W & Reddish brown & crystal & 34.20 & 17.10 \\
AP-X & Reddish brown & crystal & 19.30 & 9.65 \\
AP-Y & Whitish-blue & Gummy & 3.20 & 1.60 \\
AP-Z & Orange & Oily & 1.80 & 0.90 \\
\hline
\end{tabular}

\section{In vitro Antimicrobial Assay}

In vitro antimicrobial activity of the four solvent-extracts (AP-W, AP-X, AP-Y and AP-Z) of stem bark of A. pavonina uncovered that, the ethanol extract (AP-W) and ethyl acetate extract (AP-X) demonstrated promising activity by inhibiting the growth of all bacterial and fungal species used in the study. From the results, both solvent-extracts of ethanol (AP-W) and ethyl acetate (AP-X) displayed promising activity, while the solvent extracts of chloroform (AP-Y) and n-hexane (AP-Z) displayed poor activity. This activity was noted through the observation of visible zones of inhibition around the $6 \mathrm{~mm}$ wells. Gentamicin and ketoconazole used as reference groups also displayed good activities 
against all the bacterial and fungal species used in this assay. These two reference groups validated the test methods and also proved that, the results obtained were only due to the activity of the extracts and the effects of other factors were nullified. These can be observed clearly from Figures 1 and 2 that follow.

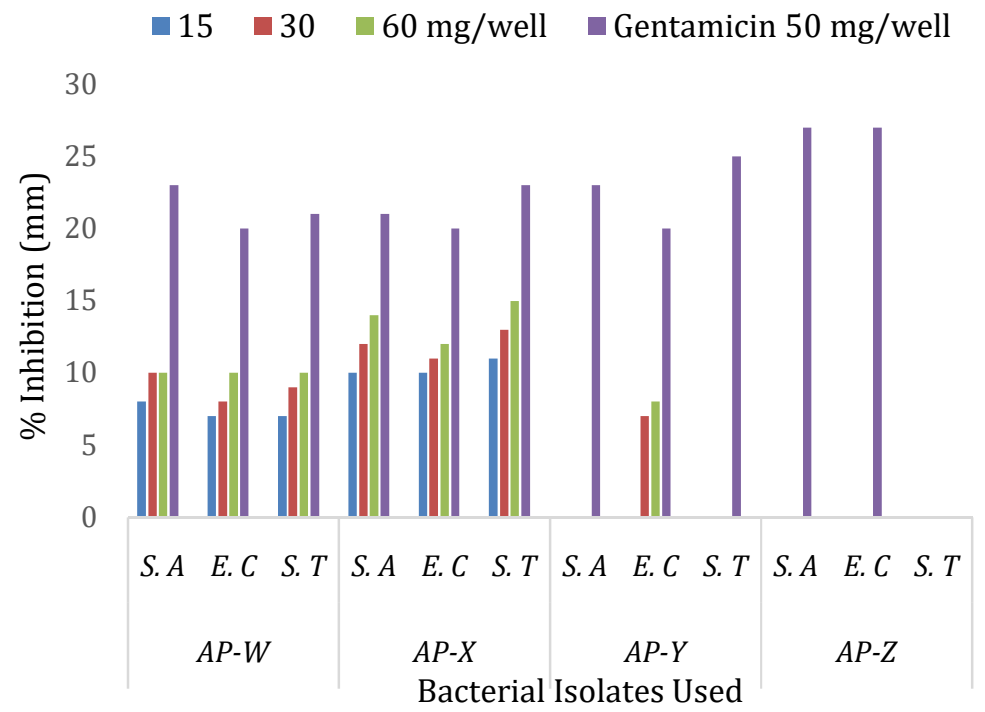

Figure 3. Activity of four different extracts and gentamicin on bacteria.

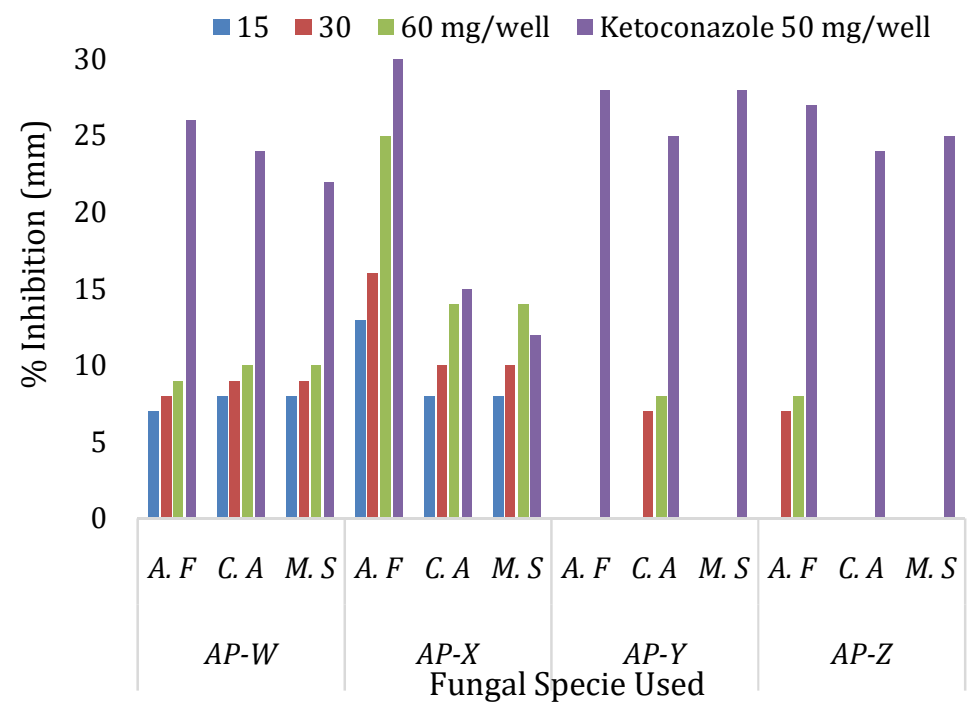

Figure 4. Activity of four different extracts and ketoconazole on fungi. 
These findings are in agreement with those reported by Hussain et al. [20], Renilda et al. [29], Mujahid et al. [14] and Abdu and Adamu [7]. The promising activities of the two extracts (AP-W and AP-X) suggested the presence of active antimicrobial secondary metabolites like alkaloids, phenols, flavonoids, sterols, tannins, glycosides among others imbedded in the stem bark of A. pavonina (Abdu and Adamu [7]).

\section{Cytotoxicity Test using Brine Shrimps (Artemia Cyst)}

The cytotoxicity test results of ethanol and ethyl acetate extracts showed observed mortality of 70 and $100 \%$ respectively at same concentration $(1000 \mu \mathrm{g} / \mathrm{mL})$ and at a concentration of $100 \mu \mathrm{g} / \mathrm{mL}$, mortality (40\%) observed with ethyl acetate extract is higher than mortality $(20 \%)$ in ethanol extract. At concentration $(10 \mu \mathrm{g} / \mathrm{mL})$ only the ethyl acetate extract was observed to have $10 \%$ mortality. Potassium dichromate (positive control) as a cytotoxic agent was observed to show mortality (100\%) at all concentrations $(1000,100$ and $10 \mu \mathrm{g} / \mathrm{mL}$ ). This cytotoxic behaviour of the extracts (AP-W and AP-X) is a further confirmation of activity. These finding can be observed apparently from Figure 5 .

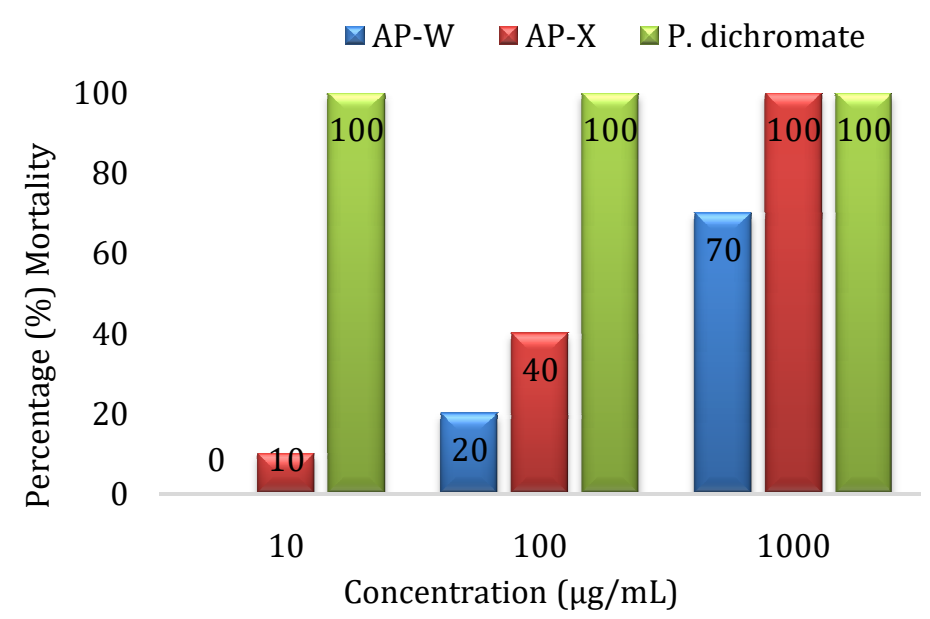

Figure 5. Cytotoxicity test results for extracts (AP-W) and AP-X) and P. dichromate.

Renilda et al. [36] carried out toxicity study on Adenanthera pavonina Linn and reported that, ethyl acetate extract was having $L C_{50}=602 \mu \mathrm{g}$ and ethanol extract $L C_{50}=$ $1387 \mu \mathrm{g}$. Meyer et al. [38], concluded that, $L D_{50}$ value of less than $1000 \mu \mathrm{g} / \mathrm{mL}$ is toxic while $L D_{50}$ value greater than $1000 \mu \mathrm{g} / \mathrm{mL}$ is non-toxic. The toxicity suggests the presence of active secondary metabolites which can be used either as antimicrobial, antitumour, antiinflamatory or insecticidal agent. 
The antimicrobial and cytotoxicity results of the present study, uncovered solventextract of ethyl acetate (AP-X) more active than the remaining solvent-extracts (AP-W, AP-Y and AP-Z) and therefore was chosen for column chromatographic isolation of targeted antimicrobial agents.

\section{Column Chromatography}

A total of 61 fractions $\left(\mathrm{AP}-\mathrm{X}_{1}-\mathrm{AP}-\mathrm{X}_{61}\right)$ were collected in the process of column chromatographic isolation of the targeted antimicrobial compounds. Two (2) out of these numbers with $\mathrm{R}_{\mathrm{f}}$ values $0.63\left(\mathrm{AP}-\mathrm{X}_{38}\right)$ and0.70 (AP- $\left.\mathrm{X}_{44}\right)$ were selected for reconfirmation of activity because each of them appeared as a single spot on thin layer chromatographic plate and are much in quantity (AP-X $\mathrm{X}_{38}=800 \mathrm{mg}$ and $\left.\mathrm{AP}-\mathrm{X}_{44}=650 \mathrm{mg}\right)$.

\section{Antibacterial Activity of Isolated Compounds}

The antibacterial activity of the isolated compounds appeared more promising than the highly active solvent-extract of ethyl acetate, which can be seen from Figure 5.

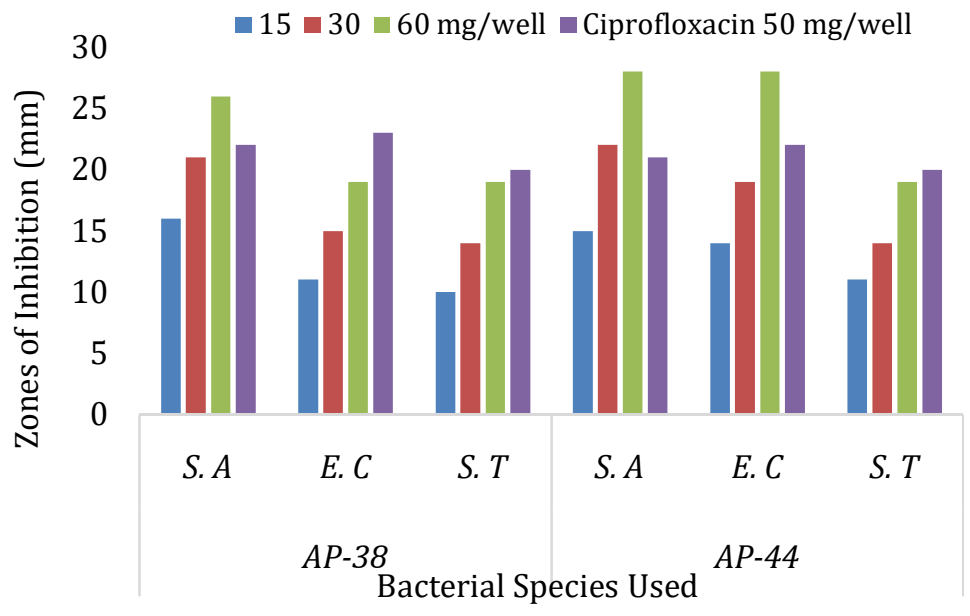

Figure 5. Antibacterial activity of isolated compounds and ciprofloxacin.

On comparing the activity of the isolated compounds (AP- $\mathrm{X}_{38}$ and $\left.\mathrm{AP}-\mathrm{X}_{44}\right)$ and that of ethyl acetate extract (AP-X), the activity of isolated compounds at lowest concentration $(15 \mu \mathrm{g} / \mathrm{mL})$ is greater than or equal to activity of ethyl acetate extract at highest concentration $(60 \mu \mathrm{g} / \mathrm{mL})$. The highest zones of inhibition measured for one of the isolated compounds was $28 \mathrm{~mm}$ and least was $10 \mathrm{~mm}$ and the highest and least zones of inhibition for ethyl acetate extract were $15 \mathrm{~mm}$ and $7 \mathrm{~mm}$ at concentrations (60 and 15 $\mathrm{mg} /$ well) respectively. Ciprofloxacin which is used as a reference standard inhibited the 
growth of all bacterial species, S. aureus (S.A), E. coli (E.C) and S. typhi (S.T) used, with a measurement $(20 \mathrm{~mm})$ as the least zone of inhibition. These phenomena can be observed clearly from Figure 6 that follows.

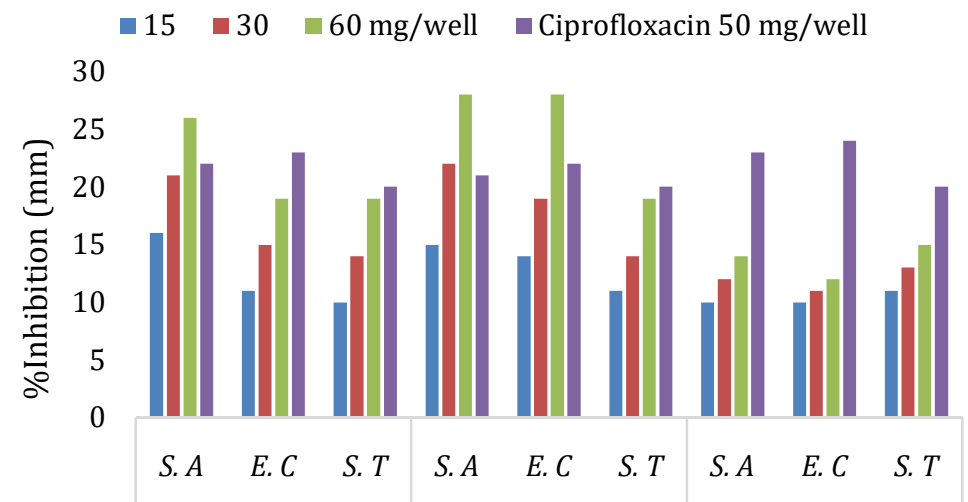

Bacterial Species Used

Figure 6. Activity comparison of isolated compounds, ethyl acetate extract and ciprofloxacin.

\section{Minimum Inhibition Concentration (MIC) of Isolated Compounds}

The minimum inhibition concentrations for the two isolated compounds were 0.5 $\mathrm{mg} / \mathrm{mL}\left(\mathrm{AP}-\mathrm{X}_{38}\right)$ and $0.25 \mathrm{mg} / \mathrm{mL}\left(\mathrm{AP}-\mathrm{X}_{44}\right)$ against E. coli, S. typhi and S. aureus. This result was determined by observing the visible growth of bacteria (turbidity of the nutrient broth) in the glass vial. This is a promising activity when compared with minimum inhibition concentration value $(12.5 \mathrm{mg} / \mathrm{mL})$ reported by Abbas et al. [37] for isolated compound ( $\beta$-sitosterol glucoside) from stem bark of $A$. pavonina. The details of this assay (MIC) are shown in Table 2 that follows.

Table 2. Minimum inhibition concentration of the isolated compounds.

\begin{tabular}{|c|c|c|c|c|}
\hline Fraction & $\begin{array}{c}\text { Conc. } \\
(\mathbf{m g} / \mathbf{m L})\end{array}$ & $\begin{array}{c}\text { S. } \\
\text { aureus }\end{array}$ & E. coli & $\begin{array}{c}\text { S. } \\
\text { typhy }\end{array}$ \\
\hline \multirow{2}{*}{$\mathrm{AP} \mathrm{X}_{38}$} & 1.0 & - & - & - \\
& 0.5 & - & - & - \\
& 0.25 & + & + & + \\
& 0.125 & + & + & + \\
\hline
\end{tabular}




\begin{tabular}{|c|c|c|c|c|}
\hline +ve control & NB + BS & + & + & + \\
- ve control & NB only & - & - & - \\
\hline & 1.0 & - & - & - \\
AP-X 44 & 0.5 & - & - & - \\
& 0.25 & - & - & - \\
+ve control & NB + BI & + & + & + \\
- ve control & NB only & - & - & + \\
\hline
\end{tabular}

\section{Conclusion}

Evidently, the results obtained for this study are indicatives that, Adenanthera pavonina is a medicinal plant that can serve as a source for the isolation of active compounds that may serve as leading compounds in antimicrobial drug development, and to be a relief for the increasing problem of antibiotic resistance. The local used of the plant in folk medicine in Southern Borno State, Nigeria, suggested that, it represent a cheaper and safer alternative in the treatment of mastitis and other infectious diseases.

This study justifies part of ethno medicinal claims on the plant, as effective as conventional medicine in combating pathogenic microorganisms of clinical and veterinary concern.

\section{Recommendation}

(i) Characterizations (GC-MS, HNMR, CNMR and FT-IR) of the isolated compounds are recommended in order to elucidate their structures.

(ii) Further antimicrobial and toxicological evaluations (In vivo) should be conducted with model animals to determine the dose dependent activity and safer usage of these isolated compounds. 


\section{References}

[1] K. Abdu and M. Adamu, Phytochemical and bioactivity studies of the stem bark extract of Adenanthera Pavonina, Proceedings of the 3rd YUMSCIC (2017), 155-160.

[2] I.E. Ezeagu, A.G. Gopal Krishna, S. Khatoon and L.R. Gowda, Physico-chemical characterization of seed oil and nutrient assessment of Adenanthera povonina L: An underutilized tropical legume, Ecol. Food Nutr. 43 (2004), 295-305.

https://doi.org/10.1080/03670240490454705

[3] C. Orwa, A. Mutua, R. Kindt, R. Jamnadass and S. Anthony, Agroforestree Database: A Tree Reference and Selection Guide Version 4.0, World Agroforestry Centre, Kenya, 2009.

[4] R.N. Chopra, S.L. Nayar and I.C. Chopra, Glossary of Indian Medicinal Plants, New Delhi: CSIR, 1956.

[5] Arshad Hussain, Md. Sarfaraj Hussain, Aliza Rizvi and Shadma Wahab, Pharmacognostical standardization of stem bark of Adenanthera pavonina L., Pharmacogn. J. 2(8) (2010), 240-246. https://doi.org/10.1016/S0975-3575(10)80100-2

[6] Mathew George, Lincy Joseph and Arun V. Venugopal, A review on antidiarrhoeal, antiinflammatory and antibacterial activity of Adenanthera pavonina leaves, Int. J. Pharmacol. Res. 7(06) (2017), 120-122.

[7] K. Abdu and M. Adamu, In vitro antimicrobial and radical scavenging activities of Adenanthera pavonina stem bark fractions, Chemsearch Journal 10(1) (2019), 58-63.

[8] Md. Mujahid, Vaseem A. Ansari, Anup K. Sirbaiya, Ranjan Kumar and Afreen Usmani, An insight of pharmacognostic and phytopharmacology study of Adenanthera pavonina, J. Chem. Pharm. Res. 8(2) (2016), 586-596.

[9] P.K.I.D.E. Jayasinghe, B.M.R. Bandara, E.W.M.A. Ekanayaka and Y. Thevanesam, Screening for antimicrobial activity of Acronychia pedunculata (Ankenda) and Adenanthera Pavonina (Madatiya) against bacteria causing skin and wound infections in humans, Peradeniya Univ. Res. Session-Sri Lanka 11 (2006), 105-105.

[10] O.A. Olajide, C.A. Echianu, A.D. Adedapo and J.M. Makinde, Anti-inflammatory studies on Adenanthera pavonina seed extract, Inflammopharmacology 12(2) (2004), 196-202. https://doi.org/10.1163/1568560041352310

[11] S. Jayakumari, V. Ravichandiran, Arun Malarkodi Velraj, Kumar Singh and A. Vijaya Lakshmi, Anti-inflammatory activity of Adenanthera pavonina Linn. Leaves, J. Nat. Rem. 12(1) (2012), 56-62.

[12] Aduragbenro D. A. Adedapo, Yeside O. Osude, Adeolu A. Adedapo, J. Olanrewaju 
Moody, Ayotunde S. Adeagbo, Olumayokun A. Olajide and Janet M. Makinde, Blood pressure lowering effect of Adenanthera pavonina seed extract on normotensive rats, Rec. Nat. Prod. 3(2) (2009), 82-89.

[13] Julia Ribeiro Soares, Andre de Oliveira Carvalho, Izabela Silva dos Santos, Olga Lima Tavares Machado, Viviane V. Nascimento, Ilka Maria Vasconcelos, Andre Teixeira da Silva Ferreira, Jonas Enrique de Aguilar Perales and Valdirene Moreira Gomes, Antimicrobial peptides from Adenanthera pavonina L. seeds: characterization and antifungal activity, Protein Pept. Lett. 19(5) (2012), 520-529.

https://doi.org/10.2174/092986612800191062

[14] M. Mujahid, H.H. Siddiqui, A. Hussain, MD. Azizur Rahman, M. Khushtar and Y. Jahan, Phytochemical analysis and evaluation of scavenging activity of methanol extract of Adenanthera pavonina linn leaves, J. Drug Discovery Ther. 5(3) (2015), 55-61.

https://doi.org/10.22270/jddt.v5i3.1147

[15] Ritika Chauhan, Hezel Lizia D’Souza, R.S. Shabnam and Jayanthi Abraham, Phytochemical and cytotoxicity analysis of seeds and leaves of Adenanthera pavonina, Res. J. Pharm. Technol. 8(2) (2015), 198-203.

https://doi.org/10.5958/0974-360X.2015.00036.0

[16] G.A.S. Kumar, R.K. Javvadi, K.V. Kumar, E.M. Reddy, Y.V. Reddy, G. Harshvardhan and M.D. Akbar, Effect of methanolic extract of Adenanthera pavonina Linn on daltons ascitic lymphoma, Indian J. Res. Pharm. Biotechnol. 1(1) (2012), 138-141.

[17] M. Mujahid, H. H. Siddiqui, A. Hussain and Md. S. Hussain, Hepatoprotective effect of Adenanthera pavonina (Linn.) against anti-tubercular drugs-induced hepatotoxicity in rats, Pharmacognosy J. 5 (2013), 286-290. https://doi.org/10.1016/j.phcgj.2013.08.003

[18] Pandhare Ramdas and Balakrishnan Sangameswaran, Extract of Adenanthera pavonina $L$. seed reduces development of diabetic nephropathy in streptozotocin-induced diabetic rats, Avicenna J. Phytomed. 2(4) (2012), 233-242.

[19] S. Das, S. Dash, A.C. Sahoo, R.K. Giri, D.C. Sahoo and P. Guru, Anti-hyperlipidemic activity of Adenanthera pavonina Linn ethanol bark extract fractions, Nature Pharmacy Technology 1(2) (2011), 1-4.

[20] Arshad Hussain, Aleza Rizvi, Shadma Wahab, Saba Ansari, Sarfaraj Hussain and Iffat Zareen, Antibacterial screening of the bark of Adenanthera pavonina (L.), Int. J. Biomed. Res. 2(2) (2011), 110-122. https://doi.org/10.7439/ijbr.v2i2.85

[21] Oluwatofunmilayo A. Adeyemi, Aduragbenro D. Adedapo, Adeolu A. Adedapo and Jones O. Moody, Evaluation of the antimicrobial activity of crude extracts and chromatographic fractions of Adenanthera pavonina Linn (Leguminosae) seeds, Afr. J. Biotechnol. 14(12) (2015), 1067-1073. https://doi.org/10.5897/AJB2015.14437 
[22] R.P. Rastogi and B.N. Mehrotra, Compendium of Indian Medicinal plants, PID, New Delhi 2 (1991), 23.

[23] N. Yadav, G. Misra and S.K. Nigam, Triterpenoids of Adenanthera pavonina bark, Planta Med. 29 (1976), 176-178. https://doi.org/10.1055/s-0028-1097649

[24] C.P. Khare, Indian Medicinal Plants. An Illustrated Dictionary, Berlin: Springer-Verlag, 2007. https://doi.org/10.1007/978-0-387-70638-2

[25] A.I. Khan and A. Khanum, Herbal medicine for human diseases, Ukaaz Publications, Hyderabad 3 (2007), 21-30.

[26] P. Binggeli, Invasive Woody Plants, 1999.

(Available at http://members.lycos.co.uk/WoodyPlantEcology/invasive/index.html)

[27] Shovon Lal Sarkar, Prianka Saha and Nigarin Sultana, In vitro evaluation of phytochemical components and antimicrobial activity of the methanolic extract of Tridax procumbens L. against pathogenic microorganisms, J. Pharmacogn. Phytochem. 5(5) (2016), 42-46.

[28] C. Azoro, Antibacterial activity of crude extract of Azadiracta indica on Salmonella typhi, World J. Biotechnol. 3 (2002), 347-357.

[29] Renilda Sophy A.J., B.S.M. Ronald., K. Gowri Shankar, R. Vidhya, Albin T. Fleming, V. Rajagopalan, A. Sheeba and R. Urgalakshmi, Antimicrobial activity of extract of Adenanthera Pavonina L. and Mussaenda Philippica against isolated Bacteria and Fungi, Int. J. Life Sci. Pharma Res. 5(4) (2015), 22-27.

[30] Mounyr Balouiri, Moulay Sadiki and Saad Koraichi Ibnsouda, Methods for in vitro evaluating antimicrobial activity: a review, J. Pharm. Anal. 6(2) (2016), 71-79. https://doi.org/10.1016/j.jpha.2015.11.005

[31] Apurbo Kumer Saha, Md. Rashidur Rahman, Masum Shahriar, Sudip Kumar Saha, Nadezda Al Azad and Susmita Das, Screening of six ayurvedic medicinal plant extracts for antioxidant and cytotoxic activity, J. Pharmacogn. Phytochem. 2(2) (2013), 181-188.

[32] Jerry L. McLaughlin, Lingling L. Rogers and Jon E. Anderson, The use of biological assays to evaluate botanicals, Drug Inf. J. 32 (1998), 513-524.

https://doi.org/10.1177/009286159803200223

[33] Wilfred M. Otang, Donald S. Grierson and Roland N. Ndip, Assessment of potential toxicity of three South African medicinal plants using the brine shrimp (Artemia salina) assay, Afr. J. Pharm. Pharmacol. 7(20) (2013), 1272-1279.

https://doi.org/10.5897/AJPP12.264 
[34] Jeremiah Oshiomame Unuofin, Gloria Aderonke Otunola and Anthony Jide Afolayan, Toxicity evaluation of Vernonia mespilifolia Less (A South Africa Medicinal Plant) using brine shrimp, J. Pharmacol. Toxicol. 12 (2017), 103-110.

https://doi.org/10.3923/jpt.2017.103.110

[35] Md. Asaduzzaman, Md. Sohel Rana, S.M. Raqibul Hasan, Md. Monir Hossain and Nittananda Das, Cytotoxic (Brine shrimp lethality bioassay) and antioxidant investigation of Barringtonia acutangula (L.), Int. J. Pharma Sci. Res. 6(8) (2015), 1179-1185.

[36] Renilda Sophy A.J., R. Vidhya, K.G. Shankar, A.T. Fleming and B.N. Rajesh, Cytotoxicity assessment of Adenanthera pavonina extracts in brine shrimp larvae and cancer cell lines, Inter. J. Vet. Sci. 5(2) (2016), 83-86.

[37] Tanveer Abbas, Faryal Liaquat, Saira Yahya, Farhana Tasleem, Iqbal Azhar and Zafar Alam Mehmood, Potential of red sandalwood (Adenanthera pavonina L.) as an antibacterial agent against clinical isolates, National Journal of Health Sciences 2(1) (2017), 61-66. https://doi.org/10.21089/njhs.22.0061

[38] B.N. Meyer, N.R. Ferrigni, J.E. Putnam, L.B. Jacobsen, D.E. Nichols and J.L. McLaughlin, Brine shrimp: A convenient general bioassay for active plant constituents, Planta Med. 45 (1982), 31-34. https://doi.org/10.1055/s-2007-971236 